УДК 343.214:340.132(477)

\title{
LEGAL CONSTRUCTION «THE SAME ACT» IN CRIMINAL LAW OF UKRAINE
}

\author{
O. Marin*, I. Sen** \\ Ivan Franko National University of Lviv, \\ 1, Universytetska Str., 79000, Lviv, Ukraine, \\ e-mail:*okmarin@ukr.net; **iryna.sen@gmail.com
}

The article deals with the issues of legislative expression of special norms (in particular, regarding the formulation of the features of qualified and especially qualified crimes) in the text of the current Criminal Code of Ukraine. For this purpose, all the cases of the use of qualified or especially qualified crimes in the Criminal Code of Ukraine are generalized in the form of a table. The main focus is on the use of the following legal formulas (constructions) for the formation of qualified and especially qualified crimes: «the same act», «the same acts», «the act(s) provided for by Part(s)... of this Article», «the same actions», «the actions provided for by Part(s)... of this Article», "the same action». An attempt is being made to analyze the content of this construction, taking into account the type of the previous core crime. In this aspect, main attention is focused on the analysis of the norm of Part 2 of Article 194 of the Criminal Code of Ukraine in order to determine the adequacy and suitability of the use of legal construction «the same act» in it. In such situations, it is proposed to assess the degree of social danger of the analyzed act, which is indicated by the so-called crime-forming features.

Keywords: legal formula (construction), qualified corpus delicti of a crime, degree of social danger, crime-forming feature.

In the Criminal Code of Ukraine, the legislator actively uses such a means of differentiation of criminal liability as a qualified crime. Quantitative analysis of the Special Part of the current Criminal Code of Ukraine gives grounds to state the following number of the use of this legal and technical means: almost 400 structural units of the Criminal Code of Ukraine contain qualified and especially qualified crimes.

It should be noted that this quantity is constantly increasing. In particular, since 2012 the number of norms containing such qualified or especially qualified crimes has increased by 36 (as of November 1, 2012, the Criminal Code of Ukraine contained 361 qualified or especially qualified crimes).

As it is known, a qualified or especially qualified corpus delicti of a crime is a legal construction that contains all the features of the main corpus delicti of a crime and additional (qualifying or especially qualifying) features that significantly change the degree of social danger of the encroachment and affect the qualification of the committed. Thus, the legislative technique for the design of qualified crimes involves the use of at least two constructive elements:

1) a reference to the core crime and

2) an indication of the relevant qualifying features.

Indication of the features of the core crime in the Special Part of the Criminal Code of Ukraine, with a few exceptions, is being made through the use of relevant legal formulas (constructions), which became the object of our research.

The relevant legal formulas (constructions), which are referred to, are the linguistic expression of the corresponding special norm (which contains a qualified or especially qualified crime), that often indicates the existence of a general norm (a norm containing

(C) Marin O., Sen I.,2017 
the core crime). Thus, one can note the regularity of the use of the constructions «the same actions», «actions provided for by Part(s)... of this Article», «the same act», «the same acts» and the like by the legislator, or the use of an indication of the title of the corresponding article of the Special Part of the Criminal Code of Ukraine or the repetition of the previous disposition.

I. Mytrofanov notes that in most cases the disposition either lists the features of a certain crime in the first part of the article or only names a crime itself, and the features that aggravate such a crime (qualified form) are indicated in the next part of the article. For this purpose, in order to avoid repeating the description of an act, the corresponding part uses the words: «the same act», «the act provided for by Part one or two of this Article», etc. [5, c. 57].

The problem is that the use of the corresponding legal formulas, to put it mildly, does not solve the issues of increasing the clarity and effectiveness of the criminal legislation, but creates problems of its understanding.

Generally speaking, as Professor V. Navrots'kyj rightly points out, there is no formal criterion for the detection of competition of at least two criminal norms and such a criterion cannot exist. Consequently, it is necessary to look for another, objective criterion for such detection. It can be an essence criterion. While applying it the attention is drawn not to the formulation of criminal norms in the law, but to the identification of their actual relationship [6, c. 286].

The problems of the use of the above-mentioned legal formulas (constructions) in the text of the current Criminal Code of Ukraine were considered by the scholars mainly in the context of the analysis of the core and qualified (especially qualified) crimes, enshrined in the norms of the separate articles of the code.

One of such problematic issues is the qualification of intentional destruction of or damage to somebody else's property (Article 194 of the Criminal Code of Ukraine) committed by way of setting fire, explosion or by any other generally dangerous method, if such actions do not cause damage in large quantities [13, c. 32]. The issue of qualification of such an act was addressed, in particular, by V. Farynnyk, N. Khlystova, O. Tatarov, I. Gazdayka-Vasylyshyn. At the dissertation level, the issue of the criminallaw characteristic of destruction of and damage to property in the Criminal Code of Ukraine was investigated by A. Semeniuk-Prybaten'.

According to V. Farynnyk, the disposition of Part 2 of Article 194 of the Criminal Code of Ukraine is formulated in such a way that in order to qualify the intentional destruction of or damage to property by fire or other dangerous method, damage in large quantities should be caused [13, c. 33]. In accordance with the definition of the Chief of the Main Investigation Department of the Ministry of Internal Affairs of Ukraine, the main argument in favor of the given position is that the qualified crime, apart from the qualifying feature, must contain all the features of the core crime. The intentional destruction of or damage to somebody else's property, that did not cause damage in large quantities, is not a criminal act (regardless of the method of its commission and other circumstances) [13, c. 35].

The same opinion is supported by O. Tatarov and I. Gazdayka-Vasylyshyn, who, referring to the Letter of the Chief of the Main Investigation Department of the Ministry of Internal Affairs of Ukraine No. 3880/0/4-12 dated March 23, 2012, state that it is possible to qualify the actions of the guilty person by Part 2 of Article 194 of the Criminal Code in cases of intentional destruction of or damage to somebody else's 
property by fire, explosion or any other generally dangerous method only if such actions cause damage in large quantities [1, c. $112 ; 10$, c. 655].

A. Semeniuk-Prybaten' adheres to a similar position and claims that in the current version of Article 194 of the Criminal Code of Ukraine intentional destruction of or damage to property, which does not cause material damage in large quantities, is not a crime regardless of the method of its commission. The main argument of the author is also the statement that the qualified crime, in addition to a qualifying feature, must contain all the features of the core crime. At the same time, the author proposes several options of legislative changes to this article in order to criminalize the intentional destruction of or damage to somebody else's property committed by fire, explosion or other generally dangerous method, if this act does not cause damage in large quantities $[9$, c. $76-80]$.

According to N. Khlystova, the opposite to the above-mentioned authors is the position of the General Prosecutor's Office of Ukraine. In its Letter-orientation «On the correct application of criminal legislation in the settlement of applications and reports on the intentional destruction of or damage to somebody else's property, committed by way of setting fire» from February 6, 2012, No. 04/2/2-141, it states that for the crime envisaged in Part 2 of Article 194 of the Criminal Code of Ukraine, if it is committed by fire or other generally dangerous method, there is no obligatory indication of causing material damage in large or extra large quantities [15, c. 423].

The purpose of this article is to determine the adequacy of the use of the legal construction «the same act...» (or similar to it) in the text of the Criminal Code of Ukraine for the purpose of carrying out tasks of efficiency and clarity of the Criminal Code of Ukraine.

Analysis of the text of the Criminal Code of Ukraine active on September 30, 2017 makes it possible to conclude that the law on criminal liability contains 397 qualified (especially qualified) crimes. It is clear that a picky researcher may question this number and he will be rightful, since certain structural units of the Special Part of the Criminal Code of Ukraine are, so to speak, of dual nature: they contain both the qualified and the core crime at the same time; concerning certain parts of the articles of the Special Part of the Criminal Code of Ukraine, the conclusion about the type of crime that they contain can only be made after solving the problem formulated in this article. Nevertheless, for illustrative purposes, it is suggested to take this very number - 397 qualified (especially qualified) crimes.

It is expedient to generalize the types of the legal constructions that the legislator uses to indicate the features of the core crime in the qualified (especially qualified) one in the form of the table.

\begin{tabular}{|c|c|c|c|c|}
\hline No. & \multicolumn{2}{|c|}{ Formulation of the construction } & Number & $\begin{array}{l}\text { Articles of the Special } \\
\text { Part of the Criminal Code } \\
\text { of Ukraine that use the }\end{array}$ \\
\hline 1. & The same actions & the core crime is formal & 96 & $\begin{array}{l}\text { P.2 Art.110; P.2 Art.127; } \\
\text { P.2 Art.135; P.2 Art.147; } \\
\text { P.2 Art.150; P.2 Art.150; } \\
\text { P.2 Art.154; P.2 Art.155; } \\
\text { P.2 Art.156; P.2 Art.161; } \\
\text { P.2 Art.162; P.2 Art.163; } \\
\text { P.2 Art.169; P.2 Art.172; } \\
\text { P.2 Art.173; P.2 Art.181; }\end{array}$ \\
\hline
\end{tabular}




\begin{tabular}{|c|c|c|c|c|}
\hline & & & & 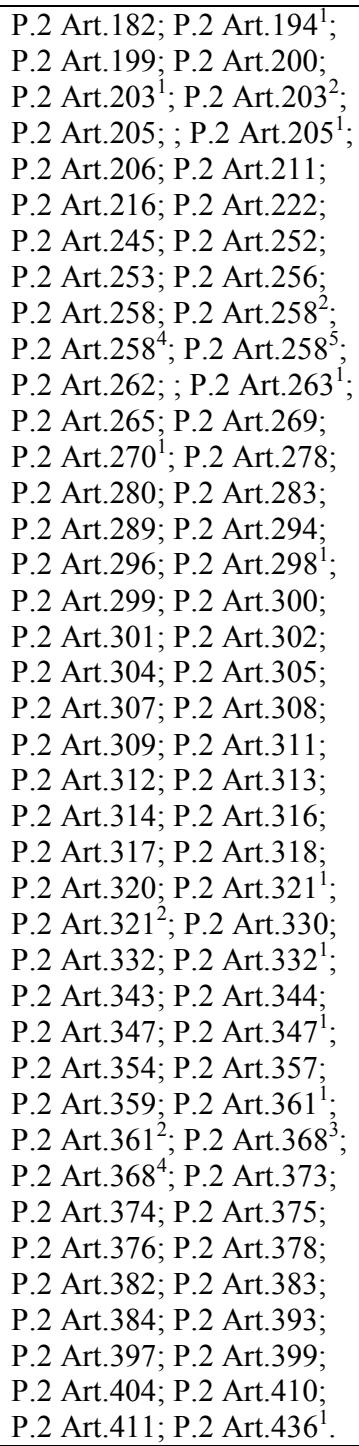 \\
\hline & & $\begin{array}{c}\text { the core crime is } \\
\text { material }\end{array}$ & 13 & $\begin{array}{l}\text { P.2 Art.122; P.2 Art.176; } \\
\text { P.2 Art.177; P.2 Art.188; } \\
\text { P.2 Art.206 } ; \text { P.3 Art.206 } \\
\text { P.2 Art.222 } ; \text { P.2 Art.229; } \\
\text { P.2 Art.248; P.2 Art.292; } \\
\text { P.2 Art.361; P.2 Art.363; } \\
\text { P.2 Art.381. }\end{array}$ \\
\hline 2. & $\begin{array}{c}\text { The actions } \\
\text { provided for by } \\
\text { Part(s)... of this } \\
\text { Article }\end{array}$ & the core crime is formal & 95 & $\begin{array}{l}\text { P.3 Art.109; P.3 Art.110; } \\
\text { P.3 Art.110²; P.4 Art.110; } \\
\text { P.2 Art.142; P.3 Art.143; } \\
\text { P.5 Art.143; P.2 Art.144; } \\
\text { P.3 Art.144; P.2 Art.149; } \\
\text { P.3 Art.149; P.3 Art.150; } \\
\text { P.3 Art.150'; P.4 Art.158; }\end{array}$ \\
\hline
\end{tabular}




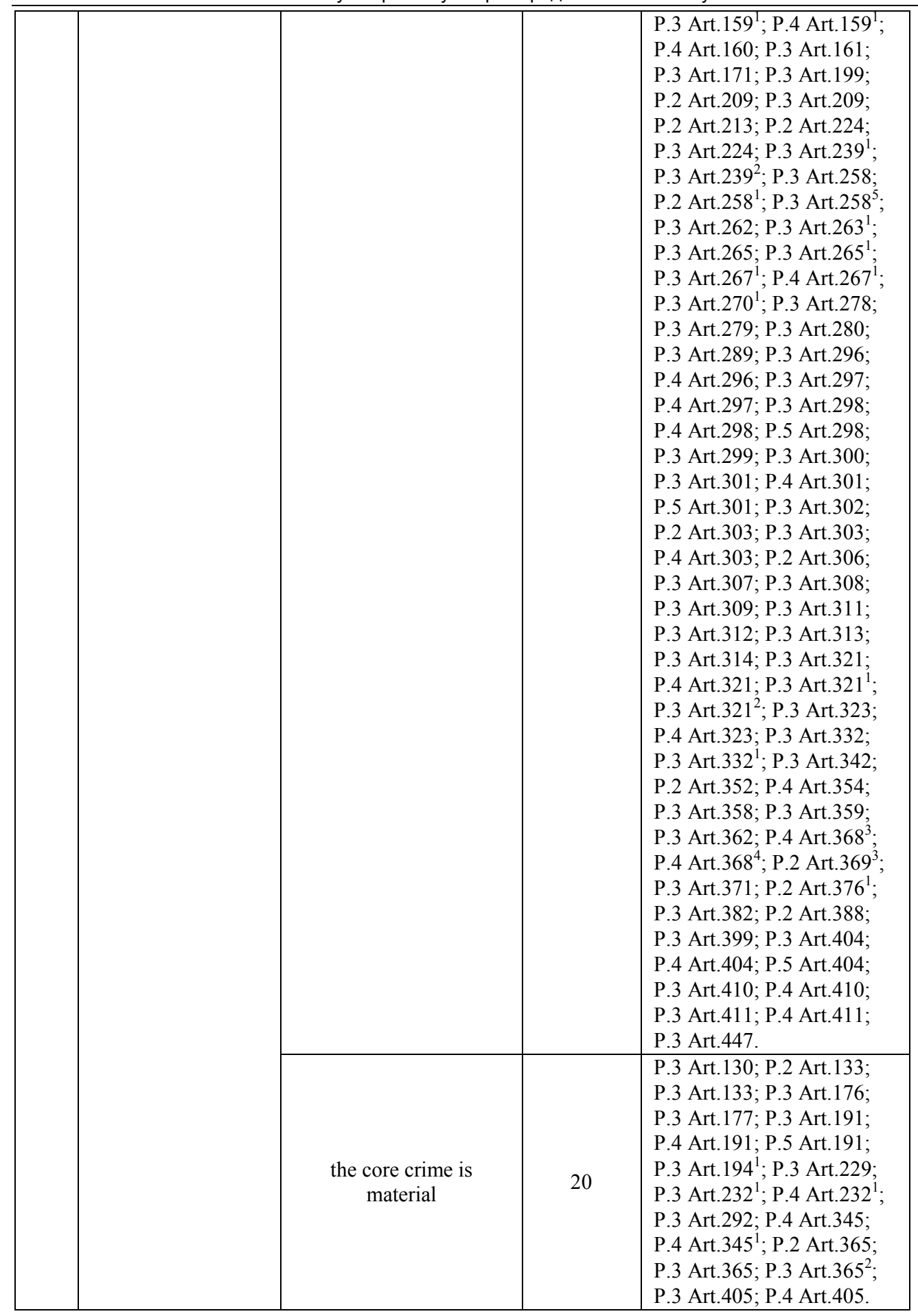




\begin{tabular}{|c|c|c|c|c|}
\hline \multirow[b]{3}{*}{3.} & \multirow{3}{*}{$\begin{array}{c}\text { The act provided for } \\
\text { by Part(s)... of this } \\
\text { Article }\end{array}$} & the core crime is formal & 8 & $\begin{array}{l}\text { P.2 Art.233; P.5 Art.260; } \\
\text { P.2 Art.368; P.3 Art.368; } \\
\text { P.4 Art.368; P.3 Art.408; } \\
\text { P.4 Art.408; P.3 Art.428. }\end{array}$ \\
\hline & & & & \\
\hline & & $\begin{array}{c}\text { the core crime is } \\
\text { material }\end{array}$ & 9 & $\begin{array}{l}\text { P.3 Art.120; P.3 Art.403; } \\
\text { P.3 Art.414; P.2 Art.415; } \\
\text { P.2 Art.418; P.3 Art.418; } \\
\text { P.3 Art.419; P.3 Art.420; } \\
\text { P.3 Art.421. }\end{array}$ \\
\hline \multirow[t]{2}{*}{4.} & \multirow[t]{2}{*}{$\begin{array}{c}\text { The acts provided } \\
\text { for by Part }(s) \ldots \text { of } \\
\text { this Article }\end{array}$} & the core crime is formal & 18 & $\begin{array}{l}\text { P.3 Art.135; P.3 Art.146; } \\
\text { P.3 Art.157; P.2 Art.158; } \\
\text { P.3 Art.240; P.4 Art.240; } \\
\text { P.3 Art.276; P.3 Art.281; } \\
\text { P.3 Art.282; P.3 Art.298; } \\
\text { P.3 Art.368 } ; \text { P.2 Art.369; } \\
\text { P.3 Art.369; P.4 Art.369; } \\
\text { P.3 Art.406; P.3 Art.409; } \\
\text { P.4 Art.409; P.3 Art.422. }\end{array}$ \\
\hline & & $\begin{array}{c}\text { the core crime is } \\
\text { material }\end{array}$ & 13 & $\begin{array}{l}\text { P.3 Art.136; P.3 Art.212; } \\
\text { P.3 Art.212 ; P.3 Art.277; } \\
\text { P.3 Art.286; P.3 Art.413; } \\
\text { P.3 Art.425; P.4 Art.425; } \\
\text { P.3 Art.426; P.4 Art.426; } \\
\text { P.3 Art.426 } ; \text { P.4 Art.426 } \\
\text { P.5 Art.426 }\end{array}$ \\
\hline \multirow[t]{2}{*}{5.} & \multirow[t]{2}{*}{ The same act } & the core crime is formal & 25 & $\begin{array}{l}\text { P.2 Art.114 } ; \text { P.2 Art.129; } \\
\text { P.2 Art.139; P.2 Art.151; } \\
\text { P.2 Art.153; P.3 Art.153; } \\
\text { P.2 Art.159; P.2 Art.164; } \\
\text { P.2 Art.165; P.2 Art.168; } \\
\text { P.2 Art.175; P.2 Art.259; } \\
\text { P.2 Art.272; P.2 Art.273; } \\
\text { P.2 Art.274; P.2 Art.275; } \\
\text { P.2 Art.328; P.2 Art.333; } \\
\text { P.2 Art.353; P.2 Art.370; } \\
\text { P.2 Art.372; P.2 Art.402; } \\
\text { P.2 Art.406; P.2 Art.428; } \\
\text { P.2 Art.439. }\end{array}$ \\
\hline & & $\begin{array}{l}\text { the core crime is } \\
\text { material }\end{array}$ & 18 & $\begin{array}{l}\text { P.2 Art.120; P.2 Art.131; } \\
\text { P.2 Art.140; P.2 Art.194; } \\
\text { P.2 Art.270; P.2 Art.271; } \\
\text { P.2 Art.326; P.2 Art.329; } \\
\text { P.2 Art.364; P.2 Art. } 364^{1} ; \\
\text { P.2 Art.365 } ; \text { P.2 Art.367; } \\
\text { P.2 Art.403; P.2 Art.414; } \\
\text { P.2 Art.419; P.2 Art.420; } \\
\text { P.2 Art.421; P.2 Art.425. }\end{array}$ \\
\hline
\end{tabular}




\begin{tabular}{|c|c|c|c|c|}
\hline \multirow[t]{2}{*}{6.} & \multirow[t]{2}{*}{ The same acts } & the core crime is formal & 17 & $\begin{array}{l}\text { P.2 Art.126; P.2 Art.146; } \\
\text { P.2 Art.157; P.2 Art.158; } \\
\text { P.2 Art.210; P.2 Art.238; } \\
\text { P.2 Art.239; P.2 Art.241; } \\
\text { P.2 Art.267; P.2 Art.276; } \\
\text { P.2 Art.281; P.2 Art.282; } \\
\text { P.2 Art.366; P.2 Art.368; } \\
\text { P.2 Art.438; P.2 Art.446; } \\
\text { P.2 Art.447. }\end{array}$ \\
\hline & & $\begin{array}{c}\text { the core crime is } \\
\text { material }\end{array}$ & 14 & $\begin{array}{l}\text { P.2 Art.137; P.2 Art.192; } \\
\text { P.2 Art.212; P.2 Art.212; } \\
\text { P.2 Art.232 } ; \text { P.2 Art.242; } \\
\text { P.2 Art.243; P.2 Art.249; } \\
\text { P.2 Art.277; P.2 Art.286; } \\
\text { P.2 Art.325; P.2 Art.412; } \\
\text { P.2 Art.413; P.2 Art.426. }\end{array}$ \\
\hline 7. & $\begin{array}{l}\text { The title of the } \\
\text { crime or the } \\
\text { repetition of the } \\
\text { previous disposition }\end{array}$ & & 42 & $\begin{array}{l}\text { P.2 Art.115; P.2 Art.119; } \\
\text { P.2 Art.121; P.2 Art.125; } \\
\text { P.2 Art.134; P.2 Art.136; } \\
\text { P.2 Art.152; P.3 Art.152; } \\
\text { P.4 Art.152; P.2 Art.185; } \\
\text { P.3 Art.185; P.4 Art.185; } \\
\text { P.5 Art.185; P.2 Art.186; } \\
\text { P.3 Art.186; P.4 Art.186; } \\
\text { P.5 Art.186; P.2 Art.187; } \\
\text { P.3 Art.187; P.4 Art.187; } \\
\text { P.2 Art.189; P.3 Art.189; } \\
\text { P.4 Art.189; P.2 Art.190; } \\
\text { P.3 Art.190; P.4 Art.190; } \\
\text { P.2 Art.191; P.2 Art.197; } \\
\text { P.4 Art.1971; P.3 Art.206; } \\
\text { P.3 Art.305; P.2 Art.310; } \\
\text { P.2 Art.327; P.2 Art.355; } \\
\text { P.3 Art.355; P.3 Art.369; } \\
\text { P.3 Art.402; P.4 Art.402; } \\
\text { P.3 Art.407; P.4 Art.407; } \\
\text { P.5 Art.407; P.2 Art.408. }\end{array}$ \\
\hline \multirow[t]{2}{*}{8.} & \multirow[t]{2}{*}{ The same action } & the core crime is formal & 8 & 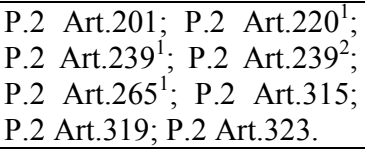 \\
\hline & & $\begin{array}{c}\text { the core crime is } \\
\text { material }\end{array}$ & 1 & P.2 Art.246. \\
\hline
\end{tabular}

The most appropriate construction for the indication of the previous (core) crime is either repeating the title of the crime (robbery, brigandism, rape, murder, etc.) in the second (next) part of the article of the Special Part of the Criminal Code of Ukraine, or textual reproduction of the previous part of the article. But such constructions are not abundant in the current Criminal Code of Ukraine: only about $10.6 \%$ - absolute minority of cases. $89.4 \%$ of the normative text of the Criminal Code (355 cases) for the same purposes use the construction «the same actions», «the same act» in different options (7 variants in total). Most likely, the legislator uses the mentioned construction in order to cut down the normative text and ensure the conciseness of normative language. 
Nevertheless, as noted above, by using the considered linguistic revisions to shorten the text of the Criminal Code of Ukraine, the legislator often creates problems in their understanding, which consequently reduces the clarity and effectiveness of criminal legislation.

There are no special problems with the interpretation and qualification of socially dangerous behavior if the first part of the article of the Special Part of the Criminal Code of Ukraine provides for liability for the formal crime (the absolute majority of cases $67.2 \%$ ). In this case the use of the constructions «the same actions», «the same act» in different versions denotes the previous core crime in the broadest meaning (all the features of the crime, except socially dangerous consequences). Although such a conclusion may be challenged from the theoretical point of view, in most cases the practice does not face difficulties in applying the relevant criminal norms in the considered aspect.

The bulk of the problems with such laconic and economical formulations arise in case the core crime is material, and its qualified form begins with the use of the analyzed constructions $-22.2 \%$ of cases. If the legislator carries out the differentiation of criminal liability by the line of increase (growth) in quantity or intensity of consequences - the use of the corresponding construction is in general justified; but if not - we face a controversial situation and variety of its interpretations by scholars.

Thus, the existing criminal norms, which are provided for by Parts 1 and 2 of Article 194 of the Criminal Code of Ukraine, cause problems of legal qualification, ambiguity in their application and the related acute scientific debate.

The norm of Part 1 of Article 194 of the Criminal Code of Ukraine provides for liability for the intentional destruction of or damage to somebody else's property, which caused damage in large quantities. The norm of Part 2 of this Article contains an indication of the same act committed by way of setting fire, explosion or any other generally dangerous method, or which caused material damage in extra large quantities, or caused death of people, or any other grave consequences. As a result, we face the question as to how to interpret the construction «the same act» in Part 2. In particular, whether intentional destruction of or damage to somebody else's property, committed by setting fire, explosion or any other generally dangerous method, is to be qualified by Part 2 of Article 194 of the Criminal Code of Ukraine, even if it does not cause damage in large quantities? There can be two opposite ways of interpretation.

If we proceed from the fact that the norm of Part 2 of Art. 194 is a special norm in relation to the norm of Part 1 and use the logical way of interpreting the relation between subordinating general and subordinate special norms, then the special one should contain all the features inherent in the general norm without any exception, including the criminal consequences, plus additional feature (or features) (in this case qualifying ones). Since the general norm contains a material crime and involves a consequence in the form of causing damage in large quantities, the special norm should also include this consequence. Accordingly, the act provided for by Part 2 of Art. 194 of the Criminal Code of Ukraine will be criminally unlawful only in case of causing damage in large quantities.

However, if we proceed from the linguistic interpretation of the term «act», we get a contradiction. A criminal act as a feature of the objective side of a crime is an active or passive (action or inaction) conscious and willful, socially dangerous and criminally unlawful behavior of a person. The act as a criminal law term does not include the criminal consequences that may be caused as a result of its commission. Accordingly, in Part 2 Art. 194 of the Criminal Code of Ukraine, the construction «the same act» shall be interpreted only as intentional destruction of or damage to somebody else's property, regardless of the damage caused. 
Consequently, there are two contradictory ways of interpretation. If the first one proceeds from the relation between general and special (which provides for a qualified crime) norms and corresponds to it completely, the other one is not so simple. It implies that the special norm does not necessarily include all the features of the general norm and this statement contradicts to the logical relation of subordination.

Accordingly, one should refer to the classification of special norms, which is offered by Professor V. Kudrjavcev, in particular the allocation of complete and incomplete (partial) competition of general and special norms. Thus, in the case under consideration, the competition between general and special norms will be incomplete (partial) - that is when a certain norm is special in relation to another norm only in certain cases [4, c. 260-261]. Thus, in Article 194 of the Criminal Code of Ukraine, the norm of Part 2 will be special in relation to the norm of Part 1 only in case of causing damage in large quantities. If such damage is not caused, but the act was committed by setting fire, explosion or by any other generally dangerous method, or it caused death of people or other grave consequences, then we have an independent norm in Part 2 of the Article which is not special in relation to the norm of Part 1.

M. Svidlov [8] names these norms relatively special, since they have only partially special nature.

To confirm this interpretation, one can refer to the explanations of the Plenum of the Supreme Court of the USSR, which have already lost validity: «With regard to such a method of committing a crime as setting fire, the courts are advised to keep in mind that criminal liability for intentional destruction of or damage to state, collective property and personal property of citizens committed by fire should be applied irrespective of whether the damage is significant» $[10$, c. $654 ; 7$, ст. 1$]$.

In practice, there are also cases of such qualification. The Decision of the joint session of the Board of Judges of the Chamber of Criminal Cases of the Supreme Court of Ukraine and the Military Board of Judges of April 3, 2009 is an example. It states that «the court reached a grounded conclusion of the fault of $\mathrm{F}$. in the crime provided for in Part 2 of Art. 194 of the Criminal Code, and for this crime, committed by way of setting fire, explosion or by any other generally dangerous method, causing material damage in large or extra large quantities is not an obligatory feature» [10, c. 655; 12].

Another example of such qualification is enshrined in the Decision of the Board of Judges of the Chamber of Criminal Cases of the Supreme Court of Ukraine of August 31, 2010. This decision confirmed the verdict of the Chyhyryn district court of Cherkasy region of December 21, 2009 in part of the qualification of the convict's actions by Part 2 of Article 194 of the Criminal Code (as intentional destruction of somebody else's property committed by setting fire). Nevertheless, «such a qualifying feature as causing damage in large quantities» was excluded from the qualification of his actions under Part 2 of Article 194 of the Criminal Code [11]. The reason for such a decision of the Supreme Court was the fact that the caused to the victim material damage in the amount of 24311.83 hryvnas, did not constitute damage in large quantities, since at the moment the crime was committed, in order to be considered in large quantities the damage should have amounted to more than 75625 hryvnas [10, c. 654-655].

Unfortunately, after the entry into force of the new Criminal Procedural Code of Ukraine on November 19, 2012, where in Part 1 of Article 458 the general obligation of the conclusions of the Supreme Court of Ukraine stated in its decisions is stipulated, the court has not considered such cases. Therefore, at the present time the issue remains unsolved.

Obviously, the best way out of the outlined problem would be the cosmetic improvement of the current text of the Criminal Code of Ukraine in this part, namely: the 
use of the titles of the crimes or the textual reproduction of the disposition of the core crime in the corresponding part of the article of the Special Part. But it is difficult and sometimes even impossible to achieve this.

In the current situation, it seems relevant to use, as V. Navrots'kyj suggests, the essence criterion to identify the actual correlation of criminal norms [6, c. 286]. In our opinion, it is necessary to take into account such theoretical considerations as to the assessment of the degree of social danger of the committed act. The crime in its material characteristics differs from the socially neutral (positive, harmful, or any other) behavior by social danger. The indicators of the social danger of criminally unlawful behavior are the so-called crime-forming features. In other words, the relevant acts are considered socially dangerous and are included to the criminal codes only if the legal characteristics of these acts include the necessary crime-forming features [14, c. 187-189].

Selection of features for the formation of the corpus delicti of a crime and the creation of the relevant criminal norm on this basis is carried out within the framework of criminalization, that is, in the process of identifying the socially dangerous forms of individual behavior, the recognition of admissibility, the possibility and feasibility of criminal struggle against them and their fixation in the law as criminally unlawful and punishable. As a result of criminalization, the features that distinguish a criminal act and non-criminal behavior are detected and enshrined in the criminal law [2, c. 11-12].

These features may relate not only to the form and type of guilt, the motive and purpose, the manner of committing a crime, the severity of the consequences, but also to the subject-matter of a crime and the victim, the place, the time, the circumstances, the situation of committing an act, the means and tools with the use of which a crime is committed, the subject. If none of these features are available, then there is no reason to say that such an act is socially dangerous [14, c. 187-189].

Such features are crime-forming, that is, those that create a norm which establishes criminal liability. The crime-forming features serve as a criterion for criminalization. Not each feature of a crime can be crime-forming. It becomes such in cases when it creates an independent criminal norm, which, following the needs of legal technique, is provided for either in the core crime or in its qualified or especially qualified forms [2, c. 11-12].

If we proceed with the analysis of the crime enshrined in Part 1 of Article 194 of the Criminal Code of Ukraine, we can conclude that in this case the quantity of the damage caused by intentional destruction of or damage to somebody else's property is the crimeforming feature. In the case described in Part 2 of Article 194 of the Criminal Code of Ukraine the emphasis of social danger «is transferred» to other factors, which are already so dangerous by themselves that convert simply illegal behavior into a crime:

1) generally dangerous method;

2) death of people;

3) other grave consequences.

Therefore, if intentional destruction of or damage to somebody else's property is committed by way of setting fire, explosion or any other generally dangerous method, or caused death of people and other grave consequences (another nature of damage caused by the crime, obviously different from its material expression in Part 1 of Article 194 of the Criminal Code) - it is not a qualified type of intentional destruction of or damage to somebody else's property, but another independent core crime. Accordingly, the norm of Part 2 of Article 194 of the Criminal Code of Ukraine is relatively special, since it has only partially special nature. That is, the encroachment stipulated in Part 2 of Art. 194 of the Criminal Code of Ukraine is a qualified crime in the proper sense of the word in relation to Part 1 only if intentional destruction of or damage to somebody else's property causes material damage in extra large quantities. 
In other words, the crime of intentional destruction of or damage to somebody else's property committed by generally dangerous method or which caused death of people or other grave consequences does not imply the existence of socially dangerous consequences in the form of causing damage in large quantities.

Conclusions. The analysis of the text of the Criminal Code of Ukraine gives grounds for the following conclusions:

- As of September 30, 2017, the Criminal Code of Ukraine contains 397 qualified and especially qualified crimes. To indicate the features of the core crime in the qualified (especially qualified) one the legislator gets to use different legal formulas (constructions).

- The most appropriate construction is either repeating the title of a crime in the second (next) part of the article of the Special Part of the Criminal Code of Ukraine, or the textual reproduction of the disposition of the previous part of the article. But such constructions are rare in the current Criminal Code -only 42 -the absolute minority of cases.

- In order to cut down the normative text, in $89.4 \%$ of the text of the Criminal Code of Ukraine (355 cases) the legislator uses the construction «the same actions», «the same act» in different options ( 7 variants in total), often creating problems in the understanding of the corresponding norms.

- If the first part of an article of the Special Part of the Criminal Code of Ukraine provides for liability for the formal crime, in most cases there are no special problems with the interpretation and qualification of the corresponding socially dangerous behavior.

- The bulk of the problematic issues of qualification arise in cases when the core crime is material, and the qualified or especially qualified one as an indication of the main crime uses by the terms «action(s)» or «act(s)». In some cases, this creates a controversial situation and acute scientific debate for its solution.

- In our opinion, in this situation it is necessary to consider the essence criterion and to proceed from the assessment of the degree of social danger of the committed act, the indicators of which are the so-called crime-forming features. If such feature or features are so socially dangerous that they create an independent criminal norm, then it can be stated that in the corresponding (second or next) part of the article of the Criminal Code of Ukraine there is a separate independent crime that does not necessarily contain all the features of the core crime, provided for in the first part of the considered article. In this case, different interpretation would indicate a gap in the criminal and legal regulation of the liability for the relevant encroachment.

- If to analyze the crime provided for by Part 2 of Art. 194 of the Criminal Code of Ukraine, dangerous method, death of people or other grave consequences are, to our mind, the crime-forming features. Therefore, the consequence of causing damage in large quantities is not an obligatory feature of this crime. Accordingly, the norm of Part 2 of Article 194 of the Criminal Code of Ukraine is relatively special, since it has only partially special nature - in terms of causing material damage in extra large quantities.

- Thus, the crime of intentional destruction of or damage to somebody else's property committed by generally dangerous method or which caused death of people or other grave consequences does not imply the existence of socially dangerous consequences in the form of causing damage in large quantities.

\section{Список використаних джерел}

1. Газдайка-Василишин І. Б., Шикор В. Я. Кримінально-правова характеристика підпалів транспортних засобів [Текст] // Митна справа. 2015. № 1 (97). Частина 2, книга 1. С. 106-117.

2. Гейн А. К. Цель как криминообразующий признак: Автореферат дисс.канд. юрид. наук: 12.00.08 [Текст] / научн. рук. С. Н. Сабанин. Тюмень, 2010. 18 с. 
3. Кримінальний кодекс України / Верховна Рада України: офіц. текст: Закон, Кодекс від 05.04.2001 № 2341-III; [редакція від 03.09.2017]. URL: http://zakon2.rada.gov.ua/laws/show/2341-14.

4. Кудрявцев В. Н. Теоретические основы квалификации преступлений [Текст]. Москва: Гос. изд-во юрид. лит-ры, 1963. 323 с.

5. Митрофанов I. I. Норма та стаття закону про кримінальну відповідальність: проблеми співвідношення [Текст] // Науковий вісник міжнародного гуманітарного університету. Збірник наукових праць. - Випуск 1. Одеса, 2011. С. 54-58.

6. Навроцький В. О. Основи кримінально-правової кваліфікації: Навчальний посібник [Текст]. Київ: Юрінком Інтер, 2006. 704 с.

7. Постановления Пленума Верховного Суда СССР от 02 марта 1989 г. «О практике применения судами законодательства по делам, связанным с пожарами» // Бюллетень Верховного Суда СССР. 1989. № 3.

8. Свидлов Н. М. Специальные нормы в уголовном праве: Автореферат дисс. канд. юрид. наук: 12.00 .08 [Текст]. - Москва: Московская высшая школа милиции МВД СССР,1979. 19 с.

9. Семенюк-Прибатень А. В. Кримінально-правова характеристика знищення та пошкодження майна за кримінальним кодексом України [Текст]: дис. ... кандидата юрид. наук: 12.00.08; Львівський державний університет внутрішніх справ. Львів, 2016. 241 с.

10. Татаров О. Ю., Газдайка-Василишин І. Б. Умисне знищення або пошкодження майна, вчинене шляхом підпалу, вибуху чи іншим загальнонебезпечним способом: проблеми кваліфікації [Текст] // Актуальні проблеми держави і права. 2012. № 65. С. 650-659.

11. Ухвала Колегії суддів Судової палати у кримінальних справах Верховного Суду України від31 серпня 2010 року. Архів ВСУ України. 2010 рік.

12. Ухвала спільного засідання колегії суддів Судової палати у кримінальних справах ВСУ і військової судової колегії від 03.04.2009 року.

13. Фаринник В. І. Проблемні питання кваліфікації умисного знищення або пошкодження чужого майна, вчиненого шляхом підпалу [Текст] // Основні напрями розвитку кримінального права та шляхи вдосконалення законодавства України про кримінальну відповідальність: матеріали міжнародн. наук.-практ. конф., 11-12 жовтня 2012 р. / редкол.: В. Я. Тацій (головн. ред.), В. І. Борисов (заступн. головн. ред.) та ін. Харків: Право, 2012. C. 31-37.

14. Хавронюк М. І. Кримінальне законодавство України та інших держав континентальної Європи: порівняльний аналіз, проблеми гармонізації: Монографія [Текст]. Київ: Юрисконсульт, 2006. 1048 с.

15. Хлистова Н. Б. Тлумачення об'єктивної сторони злочинів, передбачених ст. 194 КК України (умисне знищення або пошкодження майна), та їх значення для кримінальноправової кваліфікації [Текст] // Кримінальний кодекс України 2001 р.: проблеми застосування та перспективи удосконалення: тези доповідей та повідомлень учасників Міжнародного симпозіуму, 21-22 вересня 2012 року. Львів: Львівський державний університет внутрішніх справ, 2012. С. 422-425.

\section{References}

1. Gazdayka-Vasylyshyn, I. B., Shykor, V. Y. (2015). Kryminal'no-pravova kharakterystyka pidpaliv transportnykh zasobiv. Mytna sprava,1 (97), part 2, book 1, 106-117.

2. Gejn, A. K. (2010). Cel' kak kriminoobrazujushhij priznak. Dissertation Abstracts. Tjumen'.

3. The Criminal Code of Ukraine. (2001, April 5). Supreme Council of Ukraine. Retrieved from http://zakon2.rada.gov.ua/laws/show/2341-14.

4. Kudrjavcev, V. N. (1963). Teoreticheskie osnovy kvalifikacii prestuplenij. Moscow: State Publisher of Legal Literature. 
5. Mytrofanov, I. I. (2011). The Norms and Provisions of Law on Criminal Responsibility. Naukovyj visnyk mizhnarodnoho humanitarnoho universytetu: Zbirnyk naukovykh prats', 1, 54-58.

6. Navrots'kyj, V. O. (2006). Osnovy kryminal'no-pravovoi kvalifikatsii. Kyiv: Yurinkom Inter.

7. O praktike primenenija sudami zakonodatel'stva po delam, svjazannym s pozharami. (1989, March 2). Postanovlenija Plenuma Verhovnogo Suda SSSR.

8. Svidlov, N. M. (1979). Special'nye normy v ugolovnom prave. Dissertation Abstracts. Moscow: Moskovskaja vysshaja shkola milicii MVD SSSR.

9. Semeniuk-Prybaten', A. V. (2016). Kryminal'no-pravova kharakterystyka znyschennia ta poshkodzhennia majna za kryminal'nym kodeksom Ukrainy. Dissertation Abstracts. Lviv: Lvivs'kyj derzhavnyj universytet vnutrishnikh sprav.

10. Tatarov, O. Y., \& Gazdayka-Vasylyshyn, I. B. (2012). Deliberate destruction or damage to property committedby arson, explosion or other publicly dangerous method: problems of qualification. Aktual'ni problem derzhavy I prava, 65, 650-659.

11. Ukhvala Kolehii suddiv Sudovoi palaty u kryminal'nykh spravakh Verkhovnoho Sudu Ukrainy. (2010, August 31). Supreme Court of Ukraine.

12. Ukhvala spil'noho zasidannia kolehii suddiv Sudovoi palaty u kryminal'nykh spravakh VSU I vijs'kovoi sudovoi kolehii. (2009, April 3). Supreme Court of Ukraine.

13. Farynnyk, V. I. (2012, October 11-12). Problemni pytannia kvalifikatsii umysnoho znyschennia abo poshkodzhennia chuzhoho majna, vchynenoho shliakhom pidpalu. Osnovni napriamy rozvytku kryminal'noho prava ta shliakhy vdoskonalennia zakonodavstva Ukrainy pro kryminal'nu vidpovidal'nist': materialy mizhnarodn. nauk.-prakt. konf. Kharkiv: Pravo, 31-37.

14. Khavroniuk, M. I. (2006). Kryminal'ne zakonodavstvo Ukrainy ta inshykh derzhav kontynental'noi Yevropy: porivnial'nyj analiz, problemy harmonizatsii. Kyiv: Yuryskonsul't.

15. Khlystova, N. B. (2012, September 21-22). Tlumachennia ob'iektyvnoi storony zlochyniv, peredbachenykh st. 194 KK Ukrainy (umysne znyschennia abo poshkodzhennia majna), ta ikh znachennia dlia kryminal'no-pravovoi kvalifikatsii. Kryminal'nyj kodeks Ukrainy 2001 r.: problemy zastosuvannia ta perspektyvy udoskonalennia: tezy dopovidej ta povidomlen' uchasnykiv Mizhnarodnoho sympoziumu. Lviv: Lvivs'kyj derzhavnyj universytet vnutrishnikh sprav, 422-425.

\title{
ЮРИДИЧНА КОНСТРУКЦІЯ «ТЕ САМЕ ДІЯННЯ» В КРИМІНАЛЬНОМУ ПРАВІ УКРАЇНИ
}

\author{
O. Марін *, І. Сень ** \\ Львівський національний університет імені Івана Франка, \\ вул. Університетська, 1, 79000, Львів, Україна, \\ e-mail:*okmarin@ukr.net;**iryna.sen@gmail.com
}

Розглянуто питання законодавчого вираження спеціальних норм (зокрема, в частині формулювання ознак кваліфрікованих та особливо кваліфікованих складів злочину) в тексті чинного Кримінального кодексу України. 3 цією метою у формі таблиці узагальнено всі випадки використання кваліфікованих чи особливо кваліфікованих складів злочину в КК України. Чинний на 30 вересня 2017 року КК України дає можливість зробити висновок про те, що він містить 397 кваліфікованих (особливо кваліфікованих) складів злочину. Для позначення ознак основного складу злочину у кваліфікованому законодавець використовує різні юридичні конструкції. 
Найбільш вдалим видається відтворення у другій (наступній) частині статті Особливої частини КК України або ж назви злочину, або ж текстуальне відтворення диспозиції попередньої частини статті. Але таких конструкцій у чинному КК небагато.

Основну увагу зосереджено на використанні при конструюванні кваліфікованих та особливо кваліфікованих складів злочинів відповідних юридичних формул (конструкцій): «те саме діяння», «ті самі діяння», «діяння, передбачене (-і) частиною (-ами) ... цієї статті», «ті самі дії», «дії, передбачені частиною (-ами) ... цієї статті», «та сама дія». Зроблено спробу аналізу змісту цієї конструкції із урахуванням виду попереднього основного складу злочину.

Якщо у першій частині статті Особливої частини КК України передбачена відповідальність за формальний склад злочину, то в більшості випадків особливих проблем із тлумаченням та кваліфікацією суспільно небезпечної поведінки не виникає. Найбільше проблемних питань кваліфрікації з'являється у тих випадках, коли основний склад відповідного злочину матеріальний, а кваліфікований чи особливо кваліфікований як вказівку на основний послуговується термінами «дія(-ї)» чи «діяння».

У цьому аспекті, особливу увагу зосереджено на аналізі норми ч. 2 ст. 194 КК України з метою визначення адекватності використання у ній юридичної конструкції «те саме діяння». У подібних ситуаціях пропонуємо керуватися оцінкою ступеня суспільної небезпеки вчиненого діяння, індикатором якого $є$ так звані криміноутворюючі ознаки. У ч. 2 ст. 194 КК України, такими криміноутворюючими ознаками, на нашу думку, $€$ загальнонебезпечний спосіб, загибель людей чи інші тяжкі наслідки. Тому наслідки у виді заподіяння шкоди у великих розмірах не є обов'язковою ознакою цього складу злочину.

Отже, склад умисного знищення чи пошкодження чужого майна, вчиненого загальнонебезпечним способом або такого, що спричинило загибель людей або інші тяжкі наслідки, не передбачає наявність суспільно небезпечних наслідків у виді заподіяння шкоди у великих розмірах.

Ключові слова: юридична фрормула (конструкція), кваліфікований склад злочину, ступінь суспільної небезпеки, криміноутворююча ознака. 